\title{
OS HABITANTES DE BELO HORIZONTE “COMO OS MAIORES ADMIRADORES DO ESPORTE BRETÃO”
}

Recebido em: 13/04/2010

Aceito em: 28/08/2010

\author{
Rodrigo Caldeira Bagni Moura ${ }^{1}$ \\ Universidade Salgado de Oliveira \\ Belo Horizonte - MG - Brasil
}

\begin{abstract}
RESUMO: O objetivo central deste artigo é compreender o Futebol nas suas múltiplas expressões em Belo Horizonte nas décadas de 1920 e 1930, quando com o advento do profissionalismo, essa modalidade esportiva se organizou de outras formas, e os jogadores que se destacavam passaram a receber vantagens e incentivos financeiros para jogar. É importante também entender como a diversão, a partir do futebol, acontecia em Belo Horizonte, quais as representações presentes nas décadas de 1920 e 1930 e como a transição do amadorismo para o profissionalismo impactou as experiências dos diversos sujeitos envolvidos com esse esporte.
\end{abstract}

PALAVRAS-CHAVE: História. Esportes. Futebol.

\section{THE INHABITANTS OF BELO HORIZONTE AS THE MOST ADMIRER OF THE BRITAIN SPORT}

ABSTRACT: The central goal of this article is to understand football in its multiple expressions in Belo Horizonte in the 1920's and 1930's, when the coming of the professionalism, this sporting modality has organized itself in other ways and the players who excelled started getting advantages and financial incentives to play. It is also important to understand on how diversion from football happened in Belo Horizonte , which representations were presented in 1920's and 1930's and how the transitions from amateurism to professionalism caused impacts no the experience of several individuals involved in this sport.

KEYWORDS: History. Sports. Soccer.

\footnotetext{
${ }^{1}$ Este artigo é parte da dissertação de mestrado intitulada: “O amadorismo, o profissionalismo, os sururus e outras tramas: o futebol em Belo Horizonte nas décadas de 1920 e 1930”, defendida no programa de Mestrado em Lazer da EEFFTO da UFMG em março de 2010, sob orientação da Professora Andrea Moreno.
} 
Desde que o futebol foi se constituindo como uma das principais possibilidades de diversão do povo de Belo Horizonte ${ }^{2}$ várias opiniões sobre esse esporte começaram a ser emitidas e a conviver. Alguns viam com naturalidade o fato de "todas as vistas se voltarem primeiro para o football", mesmo que em detrimento de outras modalidades esportivas que buscavam se organizar. Outros não queriam problematizar os motivos que levavam o futebol ${ }^{3}$ a ter tanta aceitação a ponto de conseguir alterar a dinâmica da cidade e de ser o "único pensamento dos nossos sportmen" ${ }^{4}$ ". Esse processo intensificou-se na década de 1920 e promoveu um amplo debate nos jornais e revistas ${ }^{5}$.

Paulatinamente, a cidade caracterizada pelo cronista como "pobre de diversões ${ }^{6 "}$ ou como "cidade do tédio" também passou por transformações, pois as pessoas foram aos poucos ocupando a capital planejada e percebendo suas nuances, suas possibilidades e suas singularidades. Segundo Ana Fani Alessandri Carlos (2001) "Cada lugar, embora

\footnotetext{
${ }^{2}$ Belo Horizonte foi construída e planejada para ser a nova capital de Minas Gerais. Em 1894, foi nomeada uma comissão de técnicos para a sua construção e a inauguração da cidade ocorreu em 1897, a frente do projeto estava Araão Reis. O projeto para a cidade de Belo Horizonte idealizava uma ruptura com o passado político, econômico e, sobretudo, arquitetônico de Ouro Preto.

${ }^{3}$ Segundo a historiografia o primeiro time a surgir em Belo foi o Sport Club Football, em 10 de Julho de 1904, fundado por Victor Serpa e seus amigos que eram filhos de acadêmicos, de grandes comerciantes e de altos funcionários do estado. Depois de pouco tempo foram fundados mais dois clubes: o Plínio F. C, composto em sua maioria por estudantes de direito e o Club Athletico Mineiro (não sendo este o que deu origem ao atual Clube Atlético Mineiro) formado por alunos do Ginásio Mineiro. O Sport Club se dividiu em dois times, o Vespúcio e o Colombo. O Athletico também se dividiu e formou uma equipe com o mesmo nome e outra denominada "Mineiro". Assim, fundou-se a primeira liga de futebol de Belo Horizonte, composta por 3 clubes e cinco times e foi organizado o primeiro campeonato ainda em 1904. O primeiro campeonato não foi concluído, devido as fortes chuvas que atingiram a capital mineira no final de 1904 e o período de férias escolares. Para maiores informações consultar COUTO (2003), RIBEIRO (2007) ou RODRIGUES (2006).

${ }_{5}^{4}$ Arquivo da Imprensa Oficial. Minas Geraes - Domingo, 23 de Março de 1930.

${ }^{5}$ O trabalho de Meily Assbú LINHALES (2006), intitulado "A escola, o esporte e a energização do caráter: projetos culturais em circulação na Associação Brasileira de Educação (1925-1935)" traz no capítulo 2 interessantes indícios do debate sobre o esporte na década de 1920 com o pensamento de Fernando de Azevedo, Graciliano Ramos, Carlos Sussekind de Mendonça, Deputado Jorge de Moraes e Mario de Andrade. Alguns desses intelectuais fizeram referência ao futebol.

${ }^{6}$ Arquivo Público Mineiro. Revista Bello Horizonte, 9 de Novembro de 1933. A crônica encontra-se na íntegra em anexo na página 145 deste trabalho.

${ }^{7}$ Idem ao anterior.
} 
ligado a uma totalidade que se autoconstrói ao longo da história, tem sua especificidade relacionada ao entrecruzamento dos tempos diferenciados ${ }^{8,}$.

Nesse "Belo Horizonte belo", as ambigüidades perduravam e o esporte embora saudado por alguns como uma prática moderna estava associado pelos representantes dos setores mais conservadores da sociedade como "a causa de deformações physicas e, não raro, moral dos nossos jogadores ${ }^{10}$.

A tradicional sociedade mineira ${ }^{11}$, embora relutasse por aceitar o futebol, foi aos poucos se rendendo aos encantos que esse fenômeno de popularidade, entusiasmo e paixão estimulavam.

Paralelamente aos percalços e às polêmicas em torno do futebol, e/ou sendo estimulado pelo mesmo, muitas pessoas passaram a freqüentar os estádios para assistir os jogos. No calor da disputa, a animação dos presentes e a identificação com as equipes, com os jogadores e com o que os mesmos representavam foram atingindo patamares muito elevados. Alguns observadores nesse momento afirmavam que "O bellorizontino, esportivo por excellencia, vibra sempre com as boas partidas de football. Podemos qualificar os habitantes desta terra como os maiores admiradores do esporte Bretão ${ }^{12}$.

Algumas formas de diversão, como o cinema, começaram a ser substituídas pelo

futebol ou dividiam o interesse dos moradores da cidade.

\footnotetext{
${ }^{8}$ CARLOS, A. F. A. Espaço- tempo na metrópole: a fragmentação da vida cotidiana. São Paulo: Contexto,2001, p. 46.

${ }^{9}$ NAVA, 1983, p.19. Expressão de Pedro Nava utilizada como título de capítulo do seu livro "O Círio Perfeito" - Memórias VI.

${ }^{10}$ Arquivo da Imprensa Oficial. Minas Geraes - Domingo, 23 de Março de 1930.

${ }^{11}$ Esse é um indício apresentado por Tarcísio Mauro Vago (1999, p.127-128) na sua tese "Cultura escolar, cultivo de corpos: Educação Physica e Gymnastica como práticas constitutivas dos corpos de crianças no ensino público primário de Belo Horizonte (1897-1920)". O autor ao discorrer sobre o "Recreio: tempo e lugar de disputas" na escola revelou como as diretoras das escolas foram contrárias ao futebol por ser uma prática que vinha da rua, "representada como lugar pernicioso para as crianças". As resistências ao futebol, como uma prática já então popularizada, demonstram que essa modalidade esportiva "não teria lugar na escola racionalizada e disciplinada que se pretendia formadora de novos cidadãos" (1999, p.129).

${ }^{12}$ Arquivo Público Mineiro. Revista Bello Horizonte, 19 de Agosto de 1933, p.16.
} 
As matinées ficaram vazias. $\mathrm{E}$ as moças foram ver o jogo do América com o Athletico. Á noite, a Avenida já havia soffrido a influencia dos grandes acontecimentos de domingo. $\mathrm{O}$ footing era francamente americano, isto é, feito por grande número de torcedoras do América. $\mathbf{O}$ football está dominando a cidade inteira. Por isto, todos os factos locaes vivem mais ou menos na dependência da Liga Mineira. Si o Athletico bate, a Avenida Affonso Penna enche-se de moças. Si o Athletico apanha, as torcedoras não fazem o footing. Então, o domingo muda de physionomia. Outras caras. Outros sorrisos. Outras mulheres e outros homens ${ }^{13}$. (grifos meus)

De acordo com CARLOS “A produção espacial realiza-se na articulação de vários planos da realidade: no plano da vida cotidiana, aparece nos modos de apropriação, utilização e ocupação de determinado lugar, em um momento específico, revelando-se pelo uso $^{14,}$. As pessoas, nos dias de jogos dos seus times, construíam ou re-significavam os costumes, os limites e as convenções sociais. Assim, os habitantes da cidade inventavam novas formas de ocupação da mesma, de relacionamentos com os outros e de usufruírem dos espaços públicos. Uma "dose" de permissividade também podia ser evidenciada nos momentos de comemoração dos torcedores. Coisas que as pessoas não fariam no dia-dia passaram a ser possíveis nos arredores dos campos de futebol e nas horas de celebração das vitórias.

O grande envolvimento das pessoas, com essa prática em Belo Horizonte, possibilitou na década de 1930 uma expansão ainda maior do futebol pela cidade. Se antes o esporte estava circunscrito à elite da capital mineira há indícios que nos revelam que mais jogadores das áreas menos valorizadas da cidade passaram a praticar o futebol.

O football em Belo-Horizonte já se infiltrou inegavelmente em todas as camadas sociais. Nos stadiums, ao ensejo de partidas, não se nota apenas essa ou aquela determinada classe. Os jogos são assistidos por todos: o magistrado circumspecto e o propagandista bisbilhoteiro. Se antigamente era extraordinário a presença do elemento feminino,

\footnotetext{
${ }^{13}$ Arquivo da Imprensa Oficial. Minas Geraes - Segunda e Terça-feira, 1 e 2 de Junho de 1931, p.11.

${ }^{14}$ CARLOS, 2001, p. 49.
} 
hoje os campos de football tornaram-se um ponto elegante, onde as toilletes se exibem para o desfile do luxo e da vaidade. O football é sem duvida o esporte favorito ${ }^{15}$. (grifos meus)

É importante destacar a presença das mulheres nos jogos, pois em diversos momentos elas foram citadas pelos cronistas. Em alguns momentos pude perceber nos jornais que os cronistas tiravam o foco dos jogos para comentarem sobre a aparência das mulheres que estavam nos estádios. A "beleza" de algumas delas passou também a compor as crônicas nesse período.

Uma invasão na archibancada de sócios. No meio das meninas bonitas do Athletico apparecem umas creaturas que são exactamente as caras que a gente vê aos domingos na missa das 5 horas. O dr. Jayme Mattos pede uma providencia ao Fabio Brant. Mas o Fabio não pode impedir que as meninas do segundo team também compareçam. E tem para elas esta defesa boa, imitando Julio Dantas: - Meu amigo, as feias é que sabem torcer. ${ }^{16}$.

A presença feminina nos estádios nesse período pode ser considerada como um indicativo da afirmação paulatina do futebol como uma possibilidade de diversão, e embora não estivesse isento de críticas foi, aos poucos, sendo apreciado por um número cada vez maior de pessoas.

Com a maior presença das mulheres nos locais de prática do futebol, com o aumento da participação masculina nos campos, e equipes surgindo pelos inúmeros bairros $^{17}$, o número de torneios, competições e, sobretudo, a rivalidade aumentou vertiginosamente.

\footnotetext{
${ }^{15}$ Arquivo da Imprensa Oficial. Minas Gerais - Sábado, 1 de Agosto de 1931, p.10.

${ }^{16}$ Arquivo da Imprensa Oficial. Minas Geraes - Segunda e Terça-feira, 9 e 10 de Março de 1931, p.11.

${ }^{17}$ Encontrei nas fontes muitas referências a times dos mais variados bairros de Belo Horizonte. Contudo, os jornais e as revistas trazem apenas às escalações dos times da periferia ou que não participavam das competições promovidas pela liga mineira. Nesse sentido não consegui encontrar muitos vestígios da efetiva existência dessas equipes e nem muitos relatos sobre os jogadores das mesmas.
} 
Os campeonatos ${ }^{18}$ de futebol na capital mineira começaram a ser organizados e realizados logo nos primeiros anos de difusão dessa modalidade. Os indícios encontrados nas fontes permitem-me afirmar que na década de 1920 o futebol já fazia parte da vida de muitos habitantes de Belo Horizonte.

Os diversos torneios, como o Torneio Initium, promovido pela Liga Mineira de Desportos Terrestres (LMDT) estimulavam diversos níveis de envolvimento com o esporte. O que grande parte dos adeptos do jogo queriam é que as partidas corressem bem animadas, mesmo que "notando-se falta technica dos concorrentes, prova manifesta do pouco treino que tiveram"19.

Por vezes, a imprensa ${ }^{20}$ na capital mineira trouxe notícias sobre competições internacionais ou relativas a outros estados do Brasil, copas ou torneios, campeonatos ou jogos amistosos. As informações sobre o futebol contidas nos jornais versavam sobre assuntos diversificados, como o jogo que foi realizado em Paris entre as equipes

\footnotetext{
${ }^{18}$ Como já foi mencionado o primeiro campeonato de futebol da cidade de Belo Horizonte ocorreu em 1904. Em 1914 foi organizado pela recém criada Liga de Futebol de Belo Horizonte o primeiro torneio interclubes da cidade denominado de Taça Bueno Brandão (que homenageava o presidente do Estado) e foi conquistada pelo Atlético. Segundo COUTO "Em 1915, o futebol mineiro passou a ser dirigido por uma nova entidade, a Liga Mineira de Esportes Atléticos, que se responsabilizou pela organização do primeiro campeonato oficial da cidade de Belo Horizonte. A competição contou com a participação de cinco equipes: o Atlético, América, Yale, Higiênicos e Cristóvão Colombo. O Atlético tornou-se o primeiro campeão mineiro disputando sete partidas, das quais venceu cinco, empatou uma e perdeu outra. No ano seguinte o Atlético ganhou o título de campeão da cidade, no entanto, o título do campeonato mineiro ficaria com o América que o manteria até 1925". COUTO, 2003, p. 44 e 45.

${ }^{19}$ Arquivo da Imprensa Oficial. Minas Geraes - Segunda e Terça feira, 26 e 27 de Abril de 1926, p.7.

${ }^{20}$ Segundo SIMÕ̃E, 1997, p. 182-183, "A imprensa esportiva, durante a primeira fase de sua atividade na Capital (compreendida entre 1895, quando é fundado o primeiro jornal, o Bello Horizonte, e 1926, com o Correio Mineiro) comportava-se como o ilustre confrade citado por Nelson Rodrigues: uma imprensa que quando enxergava o fenômeno futebolístico - não o via plenamente como uma atividade sociabilizada, ou seja, o abordava, prioritariamente, como um trampolim físico e moral para uma mocidade sadia, privilegiando mais esses predicados, em detrimento do poder de agregação social esporte-público. Marcadamente nos primeiros anos dessa fase (e da própria imprensa da Capital), o periodismo fechava os olhos para o público de futebol. Com razão, é verdade, mas apenas nos primeiros anos, quando a assistência não representava nada além da fina flor da Capital. O futebol não demorou muito para conquistar a cidade mas a imprensa, até meados dos anos 20, enxergava apenas a bola, como o confrade lembrado por Nélson Rodrigues. E marcava, ano após ano, um gol contra, aos 45 minutos do segundo tempo e de canela".
} 
femininas da França contra equipes da Tcheco-slovaccas e Yugo-slavas, em que mais de cem mulheres foram aplaudidas pelos seus esforços em campo.

Essas informações construíram um cenário de envolvimento com esse esporte que possibilitou a participação de muitos dos interessados e construiu uma ambiência onde algumas resistências iniciais foram se esvaindo, enquanto outras permaneceram.

Muitos adeptos da modalidade começaram a dedicar o seu tempo livre prioritariamente ao futebol ocupando os campos, as arquibancadas, os diversos espaços de convivência, ora pouco freqüientados. Com grande velocidade também outros assuntos polêmicos sobre o futebol surgiam e repercutiam nos campos e nos jornais como motivos para novas resistências.

Os tradicionais pontos de encontro de Belo Horizonte passaram a acolher os espectadores das partidas e também os protagonistas dos embates, que eram reconhecidos, festejados, indagados e despertavam sentimentos controversos nos interlocutores pelas ruas e bairros da jovem capital.

O futebol era um assunto sempre presente nas rodas. Os resultados das partidas, os lances polêmicos dos jogos, o desempenho dos jogadores e as arbitrariedades eram temas de conversas que podiam se prolongar por horas ou se esvair rapidamente caso surgisse outro assunto que despertasse opiniões acaloradas.

No terço central do café, a clientela do dito, da conversa de negócio ou de ócio e a gritaria da turma do futebol. Torcedores e jogadores do Atlético, do América, do Yale, do Palestra; veteranos do Dezessete de Dezembro, do Sport Club ou dos times do campeonato de 1904 - os do Vespúcio, do Colombo, do Plínio, do Mineiro, do Estrada ${ }^{21}$.

${ }^{21}$ NAVA, 1985, p. 4. 
A rivalidade existente entre os clubes dava um colorido especial aos jogos, e foi, também, introduzida em âmbito nacional, com o advento do grande torneio que possuía representantes de alguns estados brasileiros, dentre eles, o estado de Minas Gerais. Esses torneios promovidos na década de 20 despertavam nos jogadores, no público e na imprensa o desejo de ascender no esporte elevando o nome do estado e acirrando a competição que tinha como intuito revelar quem tinha o melhor futebol do país.

Os vestígios encontrados nas fontes sugerem que nesse momento o futebol foi se transformando pela conjugação de muitos fatores. Com a exacerbação e a intensificação da competição as experiências dos "apreciadores do bello desporto bretão" caminhava para uma alteração substancial. Contudo, as rupturas que esses eventos promoviam não impediram que outras formas de viver o futebol permanecessem.

O onze Tebano ou uma fotografia de $1918^{22}$

Aí tendes, nessa fotografia, um pouco esmaecida, o único team para o qual já torci furiosamente. Depois disso, se não me engano, compareci a uma partida entre o Atlético e o Sud América (Mário, Said e Jairo), mas não senti, diante destes, a mesma emoção com que o onze distrital me encheu alguns dias da meninice...

Apezar de tudo, era um futebol ingênuo, despretensioso, e divertia. Em suma, aí tendes o team que eu amei às escondidas, sem compreender, entretanto, a sua grandeza moral. Porque em futebol, segundo o meu amigo Emilio Curtiss Lima, também há disso... (grifos meus).

Nesse momento em que o futebol crescia em popularidade diversas personagens

foram se destacando. Alguns dos jogadores, que constituíam os times, vinham do interior do estado. Muitos deles vinham para estudar em Belo Horizonte e tentavam conciliar o futebol com os livros, como foi o caso de Mário de Castro, Jairo e Said. Outros vieram para jogar futebol, convidados por emissários ou por pessoas que ao passar pelas cidades

\footnotetext{
${ }^{22}$ A narrativa é reveladora, pois o autor da crônica enfrentou o desafio de rememorar suas experiências com o futebol. Arquivo Público Mineiro. Revista Bello Horizonte. 5 de Julho de 1934.
} 
do interior procuravam garotos com potencial para atuarem nas equipes da capital, como foi o caso de Guará e Nicola.

Esses garotos conheceram o futebol nas suas respectivas cidades e aprenderam a gostar desse jogo como uma brincadeira de criança, uma diversão que os absorvia e que foi tomando conta do interior.

Há, perdido na immensidade desse Brasil a fora, um logarejo com o nome pouco harmonioso de Fundão...

Foi fundada ahi uma associação desportiva, o Futebol Club de Fundão. $\mathrm{E}$, aos domingos a rapaziada guapa da terra mete no pé os botinões travados e vae para o campo do Zico da Varge, onde se põe a castigar, furiosamente, uma esphera de couro que o club encomendou da capital. Logrou o Futebol Club de Fundão, ou melhor o F. C. F., atrahir a attenção do bom povinho fundanense, que não tem onde por a sua attenção, e faze-lo "torcedor" de um dos quadros. Sim, de um dos quadros, pois o F. C. F. tem dois, cujas forças se equilibram, o Branco e o Azul. Essa associação desencadeou verdadeiro furor, uma serie de "torcer" naquella gente que não tem o que fazer. Accendeu paixões nos corações mais accessíveis...

Por isso o futebol para os neophitos de Fundão é o jogo do "furagoal". ${ }^{23}$... (Grifos meus).

A história de Fundão inspira-me a pensar na introdução do futebol pelo interior e em Belo Horizonte, como esse esporte foi incorporado rapidamente no cotidiano das pessoas, o grande envolvimento dos habitantes das cidades e as semelhanças em alguns aspectos como: a paixão pelo futebol que enseja comparações.

Contudo, as singularidades de cada contexto foi uma preocupação constante para mim, e nesse sentido, em quais aspectos é possível comparar a cidade de Fundão com outras cidades do interior de Minas Gerais? Onde estão os pontos de sincronia e de diacronia entre essas cidades?

\footnotetext{
${ }^{23}$ Arquivo Público Mineiro. Revista Bello Horizonte. “O Sr. Dr. Delegado”. Outubro de 1938.
} 
A similitude que me instigou a estabelecer a aproximação entre esses lugares baseou-se na premissa de que o futebol foi sendo amplamente difundido pelos municípios mineiros e rapidamente foi ganhando popularidade e adesão.

Com tudo isso, alguns jovens vieram para capital do estado, seja para estudar ou para jogar futebol e ao chegarem à Belo Horizonte nos anos 1920 e 1930 os garotos que vinham do interior depararam-se com outros códigos e tiveram que aprender que esse jogo envolvia muitos elementos ainda desconhecidos ou nebulosos que aos poucos foram revelados nas suas experiências concretas.

Mário de Castro foi um desses jovens, nasceu na cidade de Formiga, localizada no oeste do estado de Minas Gerais e era filho de Lindolpho Rodrigues de Castro, proprietário de terras na sua cidade natal e que faleceu muito cedo, e Regina de Oliveira, que assumiu a família com a morte de seu esposo ${ }^{24}$. Mário de Castro veio para a capital do estado de Minas Gerais em 1925, ingressou na faculdade de medicina e morou numa república de estudantes na Rua dos Carijós.

Logo que chegou a Belo Horizonte Mário de Castro procurou o América ${ }^{25}$, que naquele ano de 1925 sagrou-se deca-campeão mineiro, acumulando os títulos desde 1916. Contudo, as fontes consultadas não permitiram-me afirmar porque o jogador não continuou nesse clube. $\mathrm{O}$ fato é que depois de pouco tempo, foi jogar no Atlético ${ }^{26}$, cujo

\footnotetext{
${ }^{24}$ GALUPPO, 2003, p.44.

${ }^{25}$ O América foi criado em 1912 por garotos que jogavam futebol na Rua da Bahia e que não passavam de 13 anos. A primeira reunião para fundar o time aconteceu em 30 de Abril de 1911, no entanto o time só duraria seis meses devido aos garotos terem compromissos com os estudos e também à falta de material para a prática do futebol. Um ano após a sua primeira fundação o América apareceria de forma definitiva. Ver COUTO, 2003, p. 46.

${ }^{26}$ O Athletico Mineiro Football Club foi fundado em 25 de Março de 1908 no parque municipal por um grupo de jovens pertencentes a tradicionais famílias mineiras. Em 1909 a equipe conseguiu seu primeiro campo para treinar e realizou a sua primeira partida oficial, vecendo o Sport Club por 3 a 0. Em 25 de Março de 1913, numa assembléia geral o time ganhou um novo nome e passou a se chamar Club Athletico Mineiro. Para maiores informações consultar COUTO, 2003, p. 44.
} 
campo ficava situado na Avenida Paraopeba, atual Avenida Augusto de Lima, do outro lado da mesma avenida estava o campo do América.

Desse momento em diante as fontes são generosas, pois as matérias dos jornais revelaram-me um grande jogador, capaz de reverter placares adversos e de despertar no público reações de admiração. É importante pensar como foi a chegada de Mário de Castro na cidade, quais foram os impactos sentidos pelo jogador que antes estava tão habituado com a sua vida no interior do estado, e como foi a sua adaptação em Belo Horizonte.

O estudante de medicina, que nas horas vagas era jogador de futebol e jogava escondido da sua família, não podia permitir que os jornais, ou a informação que ele estava jogando futebol, chegassem aos seus familiares em Formiga. Como estratégia, para impedir que isso acontecesse, Mário de Castro utilizou o pseudônimo "Orion", para que seu nome verdadeiro não fosse divulgado pela imprensa. Esse subterfúgio perdurou pelos dois primeiros anos da sua inserção no futebol em Belo Horizonte.

Algumas fontes mostraram-me que em alguns momentos era preciso que os dirigentes do Athletico implorassem para Mario de Castro jogar, o que lhe rendeu a designação de "jogador chove-não-chove"28.

Esse fato deu-me um indicativo de como o futebol era visto naquele momento por vários setores da sociedade, e como os players tinham suas experiências influenciadas, pois os mesmos eram pressionados, dentre outros fatores, por não haver uma valorização do esporte. Os jogadores ficavam indecisos, porque não viam muitas possibilidades de êxito, por mais que gostassem de jogar e praticar a modalidade, muitos acabavam

\footnotetext{
${ }^{27}$ Arquivo da Imprensa Oficial - Minas Geraes - Domingo, 12 de Junho de 1927, p.12.

${ }^{28}$ Arquivo da Imprensa Oficial - Minas Geraes - Segunda e Terça-feira, 2 e 3 de Junho de 1930, p.11.
} 
abandonando os times e os companheiros para se dedicarem a outras ocupações mais rentáveis, mais valorizadas e com maior reconhecimento.

Os jogadores, que ainda não tinham contratos com os times, podiam se recusar a jogar, como fazia Mario de Castro. Aqueles que jogavam bem queriam ser tratados com privilégios e queriam ser valorizados por todos. Do contrário, não jogavam. O profissionalismo $^{29}$ podia amenizar esse problema, mas naquele momento ainda não era uma realidade em Belo Horizonte.

Pouco depois, sozinho Mario de Castro. Instantâneos do team do Athletico. Photografias isoladas de Mario de Castro, que attende os repórteres, por ter demorado a vestir o calção. Capítulo primeiro: Mario de Castro de calção. Capitulo segundo: entrada de Mario de Castro e aplausos da archibancada. Capitulo terceiro: Mario de Castro jogará? O sujeito ficou maluco na archibancada. Mario de uniforme! Sim, todos estavam vendo. Mas o rapaz, inconveniente, queria perguntar ao próprio Mario de Castro si elle ia jogar. - Não vá - lhe disseram. Si você perguntar, elle dirá ainda que não joga. ${ }^{30}$.

Mario de Castro, quando entrava, desfilava pelos gramados um futebol de encher

os olhos e de despertar as mais diversas emoções.

\footnotetext{
${ }^{29}$ No livro "O negro no Futebol brasileiro", de Mário Filho, o autor relata que o Futebol Italiano no final da década de 1920, e na década de 1930, começou a importar muitos jogadores da Argentina, do Uruguai e do Brasil. O êxodo dos craques desses países começou a preocupar, principalmente, os Argentinos, que tinham nomes Italianos, e, assim, ficava mais fácil a inserção dos jogadores neste país: "Os grandes clubes de Buenos Aires se assustaram, todos eles tinham jogadores com nomes Italianos. Se aquilo continuasse, o que seria do futebol argentino? Só havia um remédio: o profissionalismo" (p.182).

Para Mário Filho (p.182), com a implantação do profissionalismo em Buenos Aires começou a busca de jogadores no Uruguai, pois muitos craques argentinos foram jogar na Itália, sendo necessário buscar novos craques em outros países; Montevidéu, pela proximidade com Buenos Aires, foi o primeiro local que os argentinos buscaram novos jogadores, pois não tinha jeito de competir com a Itália e repatriar os craques argentinos que foram ganhar dinheiro na Europa.

De acordo com Mário Filho, o Brasil também começou a ser alvo dos clubes no exterior que queriam os nossos craques como revela o trecho a seguir:" $\mathrm{A}$ onda do profissionalismo veio se alastrando, aproximando-se do Rio, de São Paulo. Os jornais, todos os dias traziam uma notícia: tal clube italiano pretendia tal jogador brasileiro. Às vezes não pretendia, era o jogador que dizia para assustar o clube. $\mathrm{O}$ clube assustando-se afrouxaria os cordões da bolsa." (p.182)

${ }^{30}$ Arquivo da Imprensa Oficial - Minas Geraes - Segunda e Terça-feira, 2 e 3 de Junho de 1930, p.11.
} 
Jogo violento, primitivo, que peorou a situação do Athletico. Negando o passe a Armando e jogando com violência, o Palestra desarmou o Athletico de dois Keepers para a continuação do campeonato.

Mario de Castro, o jogador insubstituível que o Brasil inteiro conhece, deu á vinte mil pessoas de ante-hontem as maiores emoções. No primeiro tempo, com um jogo surprehendente, fazendo o goal do Athletico. No segundo, desmanchando o goal que havia feito, isto é, um jogador de classe perdendo um penalty importante, antes do qual a cavallaria tinha até entrada em campo para que a gente do Palestra respeitasse a decisão do juiz ${ }^{31}$.

Depois que acabavam os jogos, Mário de Castro ainda tinha que implorar para os cronistas não escreverem o seu nome nas matérias que sairiam nos jornais, pois sua família não podia saber que ele estava jogando futebol, ao invés de estudar.

Para encerrar, isto sobre Mario de Castro. Este jogador chove-não-chove teve a coragem de pedir-nos para não incluir o seu nome na noticia do jogo, com a seguinte razão: - Minha mãe, em Formiga, não quer que eu jogue. $^{32}$.

A constatação do crescimento exponencial da modalidade e do reconhecimento do jogador de futebol, em determinados círculos sociais, convivia com o descrédito, com visões pejorativas do esporte e dos seus praticantes. O profissionalismo podia ajudar a transformar as experiências de muitas pessoas, que não mais precisariam esconder para os familiares que eram jogadores de futebol. Contudo, os registros desse debate nas fontes nos trazem indícios de que essa situação ainda perduraria por algum tempo em Belo Horizonte.

\footnotetext{
${ }^{31}$ Arquivo da Imprensa Oficial - Minas Geraes - Segunda e Terça-feira, 2 e 3 de Junho de 1930, p.11.

${ }^{32}$ Arquivo da Imprensa Oficial - Minas Geraes - Segunda e Terça-feira, 2 e 3 de Junho de 1930, p.11.
} 
Quando Regina, a mãe de Mário de Castro, descobriu que seu filho estava jogando futebol a mesma veio à Belo Horizonte com o intuito de pressiona-lo a parar de jogar e a se dedicar à sua futura profissão ${ }^{33}$.

No entanto, ao perceber que seu filho conseguia conciliar seus estudos com o futebol, Regina resolveu não mais pressioná-lo, certa de que essa decisão acabaria sendo tomada pelo seu filho.

Mário de Castro continuou no Atlético. Continuou desfilando seu futebol pelos campos, exibindo seu chute certeiro e conquistando as assistências, que começaram a buscar formas de agradá-lo e não contrariá-lo para que ele continuasse jogando.

Nas excursões do Athletico, para o interior de Minas, Mário de Castro era aclamado pela assistência. "Mario, o admirável shootador do Athletico, recebeu no sul homenagens serias, com discursos e offerecimento de presentes ${ }^{34,}$.

Numa dessas viagens o jogador relembrou a passagem do time por Varginha, Eloy Mendes e Três Pontas. Em Varginha, ao ser perguntado sobre os scores, Mário de Castro respondeu: "Isto não tem importância: cinco a dois, cinco a zero... Eu não tenho culpa: a assistência gostava de ver furar goal. Para o povo de Varginha tudo é festa. Nós sahimos de lá meio constrangidos, em difficuldade para agradecer as homenagens com que o povo nos deslumbrou ${ }^{35}$ ".

Através do relato de Mario de Castro sobre a passagem do Athletico por essas cidades pude perceber o quanto os jogadores de futebol já eram idolatrados no interior de

\footnotetext{
${ }^{33}$ GALUPPO, 2003, p. 51. Entrevista feita por Galuppo com Fileto Oliveira Sobrinho em 27 de Dezembro de 2002.

${ }^{34}$ Arquivo da Imprensa Oficial - Sexta feira, 12 de Julho de 1929, p.12.

${ }^{35}$ Arquivo da Imprensa Oficial - Sexta feira, 12 de Julho de 1929, p.12.
} 
Minas Gerais, e que a mãe de Mário de Castro tinha mesmo seus motivos para temer a permanência de seu filho num time de futebol, já que a mesma queria vê-lo formado.

\begin{abstract}
Antes de chegar a Três Pontas, passamos por esplendidas fazendas, onde nos offereceram cerveja. Na cidade, fomos recebidos pelas auctoridades locaes e pelo povo, no meio do qual havia alumnos em formatura. $\mathrm{O}$ baile no $c l u b$ Trespontano esteve optimo. No jogo vencemos. Team bom, quase equal ao de Varginha. Mas acho difícil contar tudo. Nem seria possível dar noticias de tantas festas. Só reunindo tudo numa recordação boa como a que nós trazemos de Varginha, Eloy Mendes e Três Pontas ${ }^{36}$.
\end{abstract}

Pelas palavras de Mário de Castro, que relatou algumas de suas experiências nas viagens com o time, foi possível entender um pouco melhor o que essas excursões representavam. Percebi também o quanto o futebol já era um esporte popular nesse período e diretamente associado com a diversão.

E foi assim, imerso nessa prática, que Mário de Castro foi convocado para a seleção brasileira de futebol. Tornando-se o primeiro jogador de um time mineiro a ser convidado para compor a seleção nacional. Um fato importante para época em que o futebol no Rio de Janeiro e em São Paulo eram mais organizados, detinham maior poder e possibilitavam aos jogadores maiores benefícios.

A decisão de Mário de Castro de não aceitar o convite para a seleção brasileira foi motivada por muitos fatores, como: o desejo de sua família que ele se tornasse médico, o fato de não ser esse o seu projeto de vida e a informação que ele seria reserva do atacante do Botafogo do Rio, Carvalho Leite.

\footnotetext{
${ }^{36}$ Arquivo da Imprensa Oficial - Sexta feira, 12 de Julho de 1929, p.12.
} 
Mário de Castro $^{37}$ parou de jogar em 1931. Além da sua vontade de tornar-se médico, outros aspectos podem ter contribuído para Mário de Castro ter abandonado o futebol, dentre eles: o aumento dos sururus nos campos, a intensificação da competição e o seu desencantamento pelos rumos que o esporte foi tomando na capital.

Após a conclusão do curso de medicina, na Universidade de Minas Gerais em 1934, Mário de Castro voltou para Formiga onde começou a exercer a profissão de médico. Ao voltar para Formiga ainda jogou algum tempo pelo Formiga Esporte Clube ${ }^{38}$.

Outro jovem que veio do interior para estudar em Belo Horizonte foi Jairo que nasceu na cidade de Muriaé, zona da mata mineira. Jairo veio para Belo Horizonte também para estudar medicina. Como Mário de Castro acabou dividindo o seu tempo entre o estudo e a bola ao começar a jogar no Atlético.

Jairo era encarregado de armar as jogadas, pela sua função em campo acabava atraindo a marcação. Tinha uma grande capacidade de compreensão do jogo, aliado com muita técnica.

Pela proximidade de Muriaé com o Rio de Janeiro a influência do futebol carioca na cidade mineira era muito grande. Jairo, ao vir para Belo Horizonte e ao ingressar no Atlético, também contribuiu para aumentar o interesse pelos times da capital mineira em Muriaé.

Sobre o jogo Athletico e Villa Nova, e noticiando o reapparecimento de Jairo no football, os nossos collegas do Diário da Tarde publicaram a seguinte chronica: Os encantos do jogo nocturno. A Barroca illuminada dominando a cidade. Os homens e as mulheres chegando depressa, attrahidos como bichos pela luz dos reflectores. Noite de festa na

\footnotetext{
${ }^{37}$ Segundo GALUPPO (2003), p.43, o jogador fez 195 gols em 90 jogos, o que representa uma média de aproximadamente 2,2 gols por partida. Entretanto esses dados podem e devem ser colocados sob suspeita, pois nessa época não havia ainda a preocupação de registrar e computar os dados sobre o futebol sistematicamente.

${ }^{38}$ GALUPPO, 2003, p.58.
} 
Barroca, onde o Athletico tem os seus torcedores humildes e barulhentos. $\mathrm{Na}$ entrada do campo, um scenario alegre de circo. Amendoim torrado. Laranjada. Sorvete. Meninos cavando uma entrada: - Moço, deixa eu entrar com o senhor? O garoto pobre, que nas ruas de Bello Horizonte corre atrás do Said o dia inteiro, soffre uma angustia enorme no portão da arquibancada. $^{39}$.

$\mathrm{Na}$ humildade do menino ${ }^{40}$, que implorava para entrar no estádio, foi possível identificar que alguns jogadores começaram a despontar como referências para a torcida. Como foi o caso de Carlos Brant ${ }^{41}$ que era um jovem que veio para o Athletico em 1925. Era center-half, mas jogava bem tanto de half quanto de back. Tinha boa condição técnica, além de marcar bem, passar a bola com exatidão e colocar-se bem em campo. Qualidades que o fizeram ser admirado pela torcida.

Completando o chamado "Trio maldito" do Atlético estava Said, filho de comerciantes. Seu pai morava em São Paulo e a sua mãe em Congonhas, cidade do interior de Minas Gerais. Diante dessas circunstâncias, Said morou algum tempo em São Paulo, onde jogou pelo Esporte Clube Sírio ao lado do seu irmão Pedro ${ }^{42}$.

Posteriormente, veio para Belo Horizonte para estudar. Era estudante de direito e começou a jogar no Atlético em 1926. Teve muitas dificuldades para conciliar os seus deveres na universidade com o futebol, fato pelo qual teve a conclusão do seu curso adiada por um longo tempo. Entre a universidade e o futebol priorizava o segundo, pois demonstrava muita paixão pelo esporte e dedicava muito o seu tempo a este jogo.

Said era descendente de Sírios e chegou a fundar em Belo Horizonte o time Sírio Horizontino. Pela sua identificação com o Atlético ganhou da torcida o apelido de Abi-

\footnotetext{
${ }^{39}$ Arquivo da Imprensa Oficial - Minas Gerais - Segunda e Terça-feira, 9 e 10 de Março de 1931, p.11.

40 Algumas crônicas encontradas nos jornais ajudaram-me sobremaneira a entender um pouco mais a experiência de pessoas comuns num outro tempo.

${ }^{41}$ Antes de vestir a camisa do Athletico Brant jogou no Sete de Setembro.

${ }^{42}$ GALUPPO, 2003, p. 46.
} 
chute, por causa da força do seu chute, contribuiu para estreitar as relações entre a colônia árabe de Minas Gerais com o Clube Atlético Mineiro.

Das experiências desses três jogadores algumas semelhanças devem ser ressaltadas. Tanto Mário de Castro, quanto Jairo e Said vieram estudar na capital do estado. Para as tradicionais famílias mineiras ter um curso superior e exercer uma profissão respeitada pela sociedade, como medicina ou direito, era um sinal de status e prestígio. Por outro lado, havia uma tentativa de desqualificar as atividades do tempo livre e afastar os jovens das mesmas, pois a moral da época via a diversão como uma perniciosa perda de tempo.

Nesse sentido, pude perceber nas fontes que muitos jogadores da elite mineira, sobretudo aqueles que tinham uma possibilidade de ascensão profissional numa área considerada séria e respeitada, foram pressionados por seus familiares a deixarem o futebol para dedicarem-se a uma profissão, como também foi o caso de Ricardo Pieri.

Ricardo Pieri nasceu e foi batizado em Belo Horizonte. Com seis meses de vida, sua mãe o levou para morar em Lucca, na Toscana, onde foi novamente registrado com o nome de Américo Pieri ${ }^{43}$.

Três anos depois voltou para Belo Horizonte onde passou sua infância e juventude e onde aprendeu a jogar futebol nas intermináveis "peladas" nos bairros do Barro Preto, Calafate e Prado.

Conhecido como "italianinho Américo", o morador do bairro Barro Preto - reduto da colônia italiana na capital mineira - o garoto ganhou o apelido de "Piorra" por ser um bom driblador. Em 1922, com 16 anos, o jovem começou a jogar no Palestra que treinava no Prado Mineiro.

${ }^{43}$ SANTANA, 2003, p. 39. 
Piorra jogou durante toda a sua carreira defendendo as cores da camisa tricolor do Palestra $^{44}$. Também foi o responsável por muitos passes e armações de jogadas que terminavam muitas vezes em gol. Segundo SANTANA, Piorra "foi campeão de aspirantes em 1922, virou titular em 1923, voltou a ser campeão em 1926. Mas sua melhor fase se deu jogando ao lado de Ninão, Carazo, Bengala e Armandinho, no tricampeonato de 1928-1930 ${ }^{45,}$.

Por suas grandes atuações Piorra foi várias vezes titular da seleção mineira. Nessas ocasiões o seu futebol começou a ficar em evidência e por isso foi convidado para jogar no Mackenzie de São Paulo.

No entanto, Piorra escolheu outro rumo para sua vida. Aos 32 anos encerrou sua carreira nos campos de futebol. Um dos principais motivos que o levaram a parar de jogar foi o fato de não adaptar-se aos jogos noturnos, que começaram a acontecer em Belo Horizonte a partir de 1930, com a implantação dos sistemas de iluminação nos estádios da capital mineira. Piorra foi exercer a profissão de marceneiro.

Num relato encontrado no livro de SANTANA, Piorra, aos 95 anos, afirmou quando perguntado sobre o futebol dos anos 1920 e 1930: "O jogo era pesado, com trancos e muita disputa pela bola, mas entrada maldosa, por baixo, ninguém aceitava. Se alguém batia por maldade, o tumulto no final do jogo era certo ${ }^{46,}$.

\footnotetext{
${ }^{44}$ O Palestra passou a se chamar Cruzeiro Esporte Clube em 7 de Outubro de 1942, nome que permanece até os dias atuais. Segundo COUTO, 2003, p. 55-56, "Carlos Ribeiro relata que, sem consultar o conselho deliberativo do clube, o então presidente Enne Cyro Poni divulgou à imprensa que o novo nome do Palestra seria Ypiranga Esporte Clube, em homenagem ao famoso rio situado no estado de São Paulo. Entretanto, em cinco dias, numa reunião do conselho, o novo nome foi barrado por unanimidade, quando surgiu, por sugestão do próprio presidente do conselho, Oswaldo Pinto Coelho, o nome "Cruzeiro", em homenagem à constelação do Cruzeiro do Sul, símbolo que fazia parte do brasão da República, da bandeira nacional e do exército brasileiro".

${ }^{45}$ SANTANA, 2003, p.40.

${ }^{46}$ SANTANA, 2003, p. 40.
} 
Outro jogador do Palestra chamado Octavio Fantoni, ou simplesmente Nininho, contribuiu com o seu futebol no período amador, entregando-se aos jogos com vontade, e também, teve a sua parcela de responsabilidade pela afirmação do profissionalismo no futebol mineiro e brasileiro.

Nininho, começou a jogar futebol no Botafogo, do bairro Santo Antônio. Aos treze anos foi para o time do progresso e aos catorze estreou como meia esquerda do Palestra. Em 1924 foi para a cidade de Formiga (MG) onde jogou oito meses no time do Avante e foi campeão do oeste de Minas ${ }^{47}$.

Depois dessa rápida passagem pelo interior do estado, Nininho voltou para Belo Horizonte em 1925 integrando novamente a equipe do Palestra e foi campeão mineiro em 1926, 1928, 1929, 1930. De onde só saiu para jogar na Itália em 1931.

Segundo CALDAS “os irmãos FANTONI, do Clube Athletico Mineiro, foram os primeiros jogadores a deixar o Brasil para se profissionalizarem no exterior"48. A família Fantoni, a qual o autor referiu-se, teve nesse período Nininho e Ninão que foram jogar futebol na Itália em 1931, e Niginho que, também, foi para a Itália posteriormente.

Embarcaram, quinta feira, para o Rio, com destino á Itália, os jogadores Nininho e Ninão, do Palestra que passam a pertencer ao Lazio Foot Ball $C l u b$, de Roma. O embarque daquelles dois jogadores teve o comparecimento de grande número de amigos e de representantes das nossas associações sportivas ${ }^{49}$.

Os jornais começaram a noticiar a trajetória de Nininho e de Ninão no futebol Italiano.

\footnotetext{
${ }^{47}$ SANTANA, 2003, p. 42 e 43.

${ }^{48}$ CALDAS, 1990, p. 61, equivocou-se pois todas as fontes disponíveis nos arquivos por mim visitados revelam que os irmãos FANTONI jogavam no time do Palestra, e não no Clube Athletico Mineiro como o referido autor traz no seu trabalho.

${ }^{49}$ Arquivo da Imprensa Oficial - Minas Geraes - Sabbado, 4 de Abril de 1931, p.6.
} 
Telegramma procedente de Roma informa-nos da auspiciosa estréa, nas canchas daquella cidade, dos jogadores bellorizontinos Nino I e Nininho. Pertencentes ao Palestra Itália, desta capital, Ninão e Nininho foram dos mais perfeitos jogadores de football que pizaram os nossos gramados, havendo integrado, por diversas vezes, a representação mineira no campeonato nacional. Convidados pela Lazio F. C., de Roma, os dois cracks mineiros partiram para a Itália, em princípios do mez passado, tendo já tomado parte no encontro em que esse club venceu por 3 a 0 o Peruccia F. C., um dos mais pujantes quadros romanos. Desse score, um goal foi feito por Ninão, que, como Nininho, actuou magnificamente ${ }^{50}$.

O time da Lazio, onde Ninão e Nininho jogavam, era também o time de Mussolini que tinha uma estreita relação com o clube e com o futebol, como está descrito abaixo na matéria intitulada "MUSSOLINI E O FOOT-BALL".

É sabido que o sport na Itália tem uma situação privilegiada, acarinhado e protegido pelos poderes officiaes. Mussolini tem auxiliado o sport com perfeita visão das cousas e, mercê da sua açcão neste particular, a Itália tem subido no conceito internacional. Os filhos de Mussolini, integrados na boa política do Duce, não deixam de assistir a um encontro de football em que participe o Lazio de Roma, seu grêmio favorito. O próprio Mussolini, como um simples torcedor de $c l u b$, assiste frequentemente aos desafios do Lazio e segue a vida desta collectividade. De tal maneira Mussolini demonstra sympathia pelo Lazio, que o publico já lhe chama de o "club de Mussolini. Como não se ignora nos meios sportivos brasileiros, é no Lazio que figuram os dois Fantoni - Nininho e Ninão, os magníficos players nascidos em Bello Horizonte e feitos em Bello Horizonte, de onde só sahiram para integrarem a poderosa esquadra principal do campeão de Roma, contractados especialmente para esse fim. É, pois, no próprio club das sympathias de Mussolini que estão brilhando os dois campeões bello-horizontinos, orgulho do foot-ball mineiro. Por esta ligeira nota se vê que o Duce, apesar das responsabilidades do seu cargo, não deixa de se interessar pelo sport e com tanto enthusiasmo como os mais convictos torcedores do $c l u b s^{51}$.

Em nenhuma matéria, no entanto, foi mencionado o quanto os irmãos Ninão e

Nininho recebiam para jogar futebol na Lazio. Há apenas indícios de que isso acontecia

no jornal Minas Geraes. Como descrito acima a matéria fez menção que os mesmos

foram contratados pela Lazio. Dessa forma, apesar de não serem explicitados valores ou

\footnotetext{
${ }^{50}$ Arquivo da Imprensa Oficial - Minas Geraes - Sexta-feira, 1 de Maio de 1931, p.13.

${ }^{51}$ Arquivo da Imprensa Oficial - Minas Geraes - Domingo, 31 de Maio de 1931, p13.
} 
formas de pagamento, havia algum tipo de vantagem, o que fica mais evidente no registro abaixo.

A Itália e o Foot-ball brasileiro. A Itália, ao que parece, assentou de fazer seu foot-ball o mais forte do mundo. Não conseguindo aperfeiçoa-lo com os seus próprios elementos, os homens que dirigem o foot-ball italiano têm feito rigorosa caça nos centros esportivos mais adiantados da terra, mórmente no Brasil, de onde arrancaram, mediante vantajosos honorários, excelentes jogadores. Belo horizonte sentiu fundamente a ação política esportiva italiana, com a perda dos dois $\mathrm{Ninos}^{52}$.

Diversos interesses no campo esportivo, como as gratificações que começavam a ser oferecidas para os jogadores que se destacavam em campo - em outros países e estados brasileiros - faziam vislumbrar mudanças mais radicais no amplo cenário que os jornais que circulavam pela cidade anunciavam. Um efusivo debate sobre o profissionalismo no futebol começou a ser travado pela imprensa em Belo Horizonte.

\section{Considerações finais}

Para responder os problemas que fui identificando e buscando ampliar as discussões centrei meu olhar nas experiências dos sujeitos com o futebol, tentando perceber os impactos que os jogadores sofreram nestas duas décadas e que alteraram de alguma forma a relação construída com esse esporte.

Pude perceber que o futebol fazia parte da vida das pessoas nas décadas de 1920 e 1930 em Belo Horizonte de forma arrebatadora. Outros esportes também começavam a ser mencionados, no entanto, a supremacia do futebol era notória. "Não só o football, para o qual, naturalmente, em primeiro logar, se voltam todas as vistas, mas também o tennis, o voley-ball, o basquet-ball, e outros desportos serão alvos de acurados estudos

\footnotetext{
${ }^{52}$ Arquivo da Imprensa Oficial - Minas Geraes - Sexta-feira, 10 de Julho de 1931, p.11.
} 
nos diversos processos de sua cultura ${ }^{53}$,. É importante salientar que para muitos, como está expresso acima, já era natural que o futebol fosse a preferência absoluta das pessoas.

A imprensa teve uma contribuição decisiva para a consolidação do futebol na cidade. As informações divulgadas sobre essa modalidade esportiva eram muito variadas.

A vinda de equipes de outros países e de outros estados para jogar em Belo Horizonte aconteceu algumas vezes. Os amistosos dos times da capital contra as equipes do interior aconteciam com uma regularidade considerável no período investigado. Esses intercâmbios foram importantes, pois é plausível imaginar que ao deparar-se com outras condições e com outras realidades os jogadores envolvidos com o futebol na cidade e a opinião pública começassem a reconhecer a grande paixão por esse esporte, bem como as fragilidades e as peculiaridades locais.

Em várias circunstâncias as equipes de Belo Horizonte enfrentaram os times do interior do estado, em jogos que embora tivessem um caráter festivo foram ao longo do tempo promovendo rivalidades e acirrando a competitividade no esporte. Em algumas ocasiões as equipes do interior vinham a Belo Horizonte como ocorreu com o Tupy, de Juiz de Fora, que viera enfrentar o Palestra, "A assistência encorajava com applausos os players, na defesa das suas gloriosas cores" ${ }^{\text {"54. }}$.

Em outras ocasiões, os principais times da capital foram ao interior enfrentar as equipes dos diversos municípios, tal como ocorrera na excursão do Club Athletico Mineiro a São João Del Rei. Esses jogos também tinham a finalidade de promover o futebol. "Debaixo de uma assistência numerosa, onde se destacavam elementos da maior representação social e política, alumnos dos diversos estabelecimentos e grande numero

${ }^{53}$ Arquivo da Imprensa Oficial - Minas Geraes - Domingo, 21 de Março de 1926, p.7.

${ }^{54}$ A matéria pode ser acessada no Arquivo da Imprensa Oficial - Minas Geraes - Domingo, 15 de Julho de 1928. 
de senhorinhas, realizou-se, domingo, o grande encontro inter-municipa ${ }^{55 \%}$. Havia um conjunto de rituais nesses jogos festivos que iam desde o acolhimento da equipe visitante, o momento do jogo, a cordialidade de quem recebia, os agradecimentos e o reconhecimento por parte do anfitrião e do visitante. O que não podia ser abalado, entretanto, era o confronto entre as equipes nesses jogos amistosos, "O encontro transcorreu em perfeita ordem e camaradagem não só por parte da enthusiastica assistência, como também por parte dos players, que se degladiavam ${ }^{56 "}$.

O futebol cumpriu o papel de aproximar as pessoas como nenhuma outra manifestação havia conseguido até aquele momento. É certo que outras formas de diversão foram se constituindo em Belo Horizonte no início do século XX, contudo, através dos indícios encontrados constatei que o futebol agradava a muitas pessoas nesse momento. Muitas equipes surgiram nos arredores da cidade e nos bairros periféricos.

\section{REFERÊNCIAS}

CALDAS, Waldenyr. O pontapé inicial: memória do futebol brasileiro. São Paulo: IBRASA, 1990.

CARLOS, A. F. A. Espaço-tempo na metrópole: a fragmentação da vida cotidiana. São Paulo: Contexto, 2001.

COUTO, Euclides de Freitas. Belo Horizonte e o Futebol: integração social e identidades coletivas (1897-1927). Dissertação (Mestrado em História) - PUC-MG, Belo Horizonte, 2003.

GALUPPO, Ricardo. Raça e amor: a saga do Clube Atlético Mineiro vista da arquibancada. São Paulo, 2003. (Coleção Camisa 13).

${ }_{55}^{55}$ Arquivo da Imprensa Oficial - Minas Geraes - Quarta-feira, 15 de Agosto de 1928, p.8.

${ }^{56}$ Arquivo da Imprensa Oficial - Minas Geraes - Quarta-feira, 15 de Agosto de 1928, p.8. 
LINHALES, Meily Assbú. A escola, o esporte e a "energização do caráter": projetos culturais em circulação na Associação Brasileira de Educação (1925-1935). Tese (Doutorado em Educação). Faculdade de Educação da UFMG, 2006.

NAVA, Pedro. O Círio perfeito - Memórias 6 - Rio de Janeiro: Nova Fronteira, 1983.

NAVA, Pedro. Beira Mar - Memórias 4 - 3. ed, - Rio de Janeiro: Nova Fronteira, 1985.

RIBEIRO, Raphael Rajão. A bola em meio a ruas alinhadas e uma poeira infernal: os primeiros anos do futebol em Belo Horizonte (1904-1921). Dissertação (Mestrado em História). Belo Horizonte: FAFICH/ UFMG, 2007.

RODRIGUES, Marilita A. A. Constituição e enraizamento do esporte na cidade: Uma prática moderna de lazer na cultura urbana de Belo Horizonte (1894-1920). Tese (Doutorado em História). UFMG, Belo Horizonte, 2006.

RODRIGUES FILHO, Mário. O Negro no Futebol Brasileiro. 4. ed. Rio de Janeiro: Mauad, 2003.

SANTANA, Jorge. Páginas heróicas: onde a imagem do Cruzeiro resplandece. São Paulo, 2003. (Coleção Camisa 13).

SIMÕES, Leandro Ferreira. O jornal e a bola: para onde foi a torcida? In: CASTRO, Maria Ceres Pimenta Spíndola. Folhas do tempo: imprensa e cotidiano em Belo Horizonte 1895-1926. Belo Horizonte, UFMG, 1997.

VAGO, Tarcísio Mauro. Cultura escolar, cultivo de corpos: educação physica e gymnastica como práticas constitutivas de corpos de crianças no ensino público primário de Belo Horizonte - 1897-1920. Tese (Doutorado em Educação). Faculdade de Educação, USP, São Paulo, 1999.

\section{Endereço do Autor:}

Rodrigo Caldeira Bagni Moura

Rua Pio XI, 536, apto 504 - Bairro Ipiranga

Belo Horizonte, MG. Cep 31160140.

Endereço Eletrônico: rodrigo.caldeira@ig.com.br 